Columbia College Chicago

Digital Commons @ Columbia College Chicago

Creative Arts Therapies Theses

Thesis \& Capstone Collection

$10-2009$

\title{
Trudi Schoop: Passing On Her Legacy
}

Jeff Gilbert

Columbia College - Chicago

Follow this and additional works at: https://digitalcommons.colum.edu/theses_dmt

Part of the Dance Movement Therapy Commons

(c) (i) (9)

This work is licensed under a Creative Commons Attribution-Noncommercial-No Derivative Works 4.0 License.

\section{Recommended Citation}

Gilbert, Jeff, "Trudi Schoop: Passing On Her Legacy" (2009). Creative Arts Therapies Theses. 25.

https://digitalcommons.colum.edu/theses_dmt/25

This Thesis is brought to you for free and open access by the Thesis \& Capstone Collection at Digital Commons @ Columbia College Chicago. It has been accepted for inclusion in Creative Arts Therapies Theses by an authorized administrator of Digital Commons @ Columbia College Chicago. For more information, please contact drossetti@colum.edu. 


\title{
TRUDI SCHOOP: PASSING ON HER LEGACY
}

\author{
A Thesis \\ Presented to \\ The Faculty of the \\ Dance/Movement Therapy \& Counseling Department \\ Columbia College Chicago \\ In Partial Fulfillment of the \\ Requirements for the \\ Master of Arts Degree in Dance/Movement Therapy \& Counseling \\ By \\ Jeff Gilbert
}

October, 2009 


\title{
TRUDI SCHOOP: PASSING ON HER LEGACY
}

\author{
A Thesis by \\ Jeff Gilbert
}

Approved as to style and content by:

Laura Allen, MA, R-DMT, LPC
Andrea Brown, MA, BC-DMT, NCC, LCPC
Laura Downey, MA, R-DMT, LPC, GLCMA
Lenore Hervey, Ph.D., BC-DMT, NCC, REAT
Susan Imus, MA, BC-DMT, LCPC, GLCMA
Cathy Pidek, MA, R-DMT, GLCMA
Jessica Young, MA, BC-DMT, LCPC, GLCMA

Accepted by:

Lenore Hervey, Ph.D., BC-DMT, NCC, REAT

Date

Research Coordinator and Thesis Advisor

Susan Imus, MA, BC-DMT, LCPC, GLCMA

Date

Chair, Dance/Movement Therapy \& Counseling Department 


\begin{abstract}
The purpose of this thesis project was to create a documentary style recording of a panel of dance/movement therapy professionals talking about their work with, or study of, noted dance/movement therapy pioneer Trudi Schoop at a workshop during the 2009 American Dance Therapy Association (ADTA) Conference. My research questions for the panel and its audience were: "What were the qualities about Trudi Schoop that so many people appreciated about her (what was that light)?" "What did she do to cultivate those qualities?" and "How did she pass that on to others?" (Results in Appendix C).

The audience was invited to participate with questions, comments, and their own stories about their interactions with Schoop. Additionally, audience members assisted by synthesizing the information from the workshop on a questionnaire about Schoop (the above questions). This research takes a deeper look at how Schoop was developing and using these traits, and then distills that information down to a useful summary. Findings that expand the current literature on Schoop include the panel and the audience's emotional connection to Schoop as seen in the video, Dr. Chodorow's notes of her sessions with Schoop (Appendix B), and the questionnaires from the audience.
\end{abstract}




\section{Acknowledgments}

My deepest thanks to the panel members Dr. Cynthia F. Berrol, Sharon Chaiklin, Susan D. Imus, Dr. Tina Stromsted, and Therese Adams Young, and to all the people who shared their stories about Trudi Schoop, and to Dr. Joan Chodorow whose warmth and generosity helped make this project a joy. My appreciation to Dr. Lenore Hervey whose gift of balancing flexibility with directness helped me stay connected to my vision and joy while challenging me to move outside my comfort zone and create a better product. And last but not least my heartfelt gratitude to Trudi Schoop and the body of work she left behind. It has been an incredible gift to see how many lives she touched and to see how profoundly she influenced people. She truly left behind a wake of goodness. 


\section{Table of Contents}

Introduction.........................................................

Literature Review.........................................4

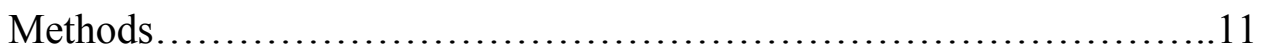

Results...................................................... 21

Conclusion..................................................27

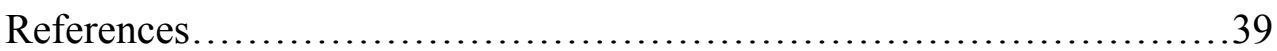

Appendix A, Glossary of Terms.................................42

Appendix B, Dr. Joan Chodorow's Notes from Schoop studies............43

Appendix C, Questionnaire results................................47

Appendix D, Biographies.......................................49

Informed Consent Form............................................ 51

DVD: ATDA Schoop Panel............................ Inside back cover 


\section{Introduction}

I have worked in a number of professional positions. I'm fascinated by life choices and paths. I have at times watched myself grow progressively deader to the world, and other times I've watched myself open, connect, and delight in life. In one particular time of deadening I was working for a large multinational company and I vividly recall a conversation of two fellow employees as we rode the elegant chrome elevators up to our floor, "You're kidding! They let Steve from Information Technology go? Damn, he was the sanest one there. I can't stand it here," and his friend looked at him and said "What are you going to do? I got the kids and the mortgage..." The elevator doors opened, and we went about another day. I was doing things that weren't horrible at work, but I didn't feel good about what I was doing. I knew that each day I was leaving the planet just a little worse than I found it and the only thing I could cling to was the thought, "everyone else is doing it, I've got to pay my bills." However, I was also getting more involved in meditation and yoga outside of work and I was waking up. I could no longer stand the pain and discomfort of doing things that didn't feel right at work. This thesis project is about joy, living and loving fully, opening to all parts of ourselves, being of service, and living with integrity. "I think we are very unhappy human beings...I think when you move you become involved and you learn to love yourself. When you love yourself you love life, you love others, you love!"' (Schoop in Wallock, 1983, p. 6)

My personal motivation for doing this research was to find out more about joy, humor, spontaneity, and interpersonal relationships as they related to Schoop's work. Although I had used a number of tools and techniques for my own personal growth and made many changes, I really appreciated what I'd read and heard from others about 
Schoop and her sense of joy and wonder. In a sense this was a study on what appeared to be Schoop's positive way of engaging the world. I first encountered Schoop in a picture in Fran Levy's book Dance Movement Therapy: A Healing Art. I had a palpable feeling of joy looking at the picture and wanted to know more about Schoop. It seemed like she had this light about her. After that, for a class project I chose Schoop to learn more about and had the good fortune to interview Dr. Joan Chodorow, one of Schoop's foremost students and a leader in the field of dance/movement therapy and counceling, over the phone and found out more about her work with Schoop. I love Dr. Chodorow's quote, "By being who she was Trudi invited others to be themselves" (2006, p. 2). Dr.

Chodorow also said of Schoop, “I couldn't be who I am without her" (2007). These comments are in keeping with how I have heard others speak of Schoop.

After my interview with Dr. Chodorow, in a class exercise where my dance/movement therapy classmates and I had the opportunity to lead each other through experientials, I led the class through one of Schoop's techniques of trying on different parent's movements, and seeing what could be learned from that. I also did this experiential myself before this class. My classmates and I found this to be an extremely illuminating experiential and learned a great deal. It was from the feeling of joy I had from looking at the picture of Schoop, my interview with Dr. Chodorow and the love she had for Schoop, and the rewarding experience I had trying out and then facilitating Schoop's experiential that I chose to learn more about Schoop. As there was not much personal information about her, I chose to do interviews and set up a panel of her students and others interested in her to talk about their work with her for my thesis. The same 
way one can learn about the "appleness of an apple" I wanted to learn about the "Schoopness of Schoop."

The purpose of my thesis project was to create a documentary style recording of a panel of dance/movement therapy professionals talking about their work with, or study of, noted dance/movement therapy pioneer Trudi Schoop. The panel took place at a workshop during the 2009 American Dance Therapy Association (ADTA) Conference. I also invited the audience of the workshop to participate with questions, comments, and their own stories about their interactions with Schoop. Additionally, I had audience members assist with synthesizing the information from the workshop by filling out questionnaires about Schoop. My research questions for the panel and workshop audience were: "What were the qualities about Trudi Schoop that so many people appreciated about her (what was that light)?" "What did she do to cultivate those qualities?" and "How did she pass that on to others?" (Results in Appendix C). The literature I reviewed often talked about Schoop's sense of humor, spontaneity and authenticity (Chodorow, 2006, p. 2). With my research I take a deeper look at how Schoop was developing and using these traits, and then distill that information down to a useful summary.

This research can be of value to dance/movement therapists and also the general population. It will offer dance/movement therapists a window into one of their founders and a few of her students, who collectively have many years of experience as dance/movement therapists. It also describes ways people can move towards health, based on Schoop's methods. There are many therapies that address removing negative patterns, and some that help address moving toward positive patterns, but not many that address joy and spontaneity the way Schoop's work does. 


\section{Literature Review}

I have seen people light up when they talk about Schoop, and I have read wonderful things written about her in the literature, describing her sense of humor, joyfulness, and ability to be present in the moment (These can be witnessed in Claudia Wilke's 1991 documentary about Schoop, Come Dance With Me.). My interest was in breaking down what it was about Schoop that people connected with so deeply, what Schoop did to cultivate those qualities, and how she passed that on to her students. This is a fairly exhaustive review of the literature on Schoop. There were only three other articles that I knew about that I did not include in my literature review because I was unable to obtain them without extensive effort and they did not seem as relevant to my work. As I mentioned in my introduction there is not a lot of literature on Schoop. That is one of the reasons I chose to do my thesis project on her, so I could learn more, and share that with others. Below is a look at what little literature there is on Schoop and I go briefly into Schoop's personal background, her theories, her methods, and how she used body-centered healing in her work.

\section{Body-Centered Healing}

We know how Schoop used dance to heal herself (Schoop in Wallock, 1983).

Schoop said in her interview with Wallock:

If I am absolutely open about it, I think I had a long period of being like a schizophrenic. I didn't talk about my praying [compulsive behavior] with anybody, because I sensed that they wouldn't understand what I was doing. All the others, my brothers and sisters were quite happy. Then I began to dance. That was very strange. We had a big front room with a record player. And I loved this 
record player. There were lots of records. I began to dance. I danced...I closed the door. Nobody could come in. I danced and danced and improvised. I danced flowers, I danced birds, clouds, danced like the trees and like the corn in the fields. I danced all the things I saw. (p. 8)

Schoop also goes on in the Wallock interview to talk more about her beliefs and theories, and discusses more of her background starting a dance troupe and growing up in Switzerland. Schoop discussed her cosmological beliefs in "Motion and emotion," a talk she gave in 1978 that was later published in the American Journal of Dance Therapy (2000). In this talk Schoop described her belief that we have two levels of experience. The first level is the " $U r$ " experience, Schoop began her talk explaining the $u r$ experience, quoted below:

... a German word. The closest translation I can find in English are such terms as "cosmic," "universal," and "transcendent." The $u r$ principle denotes the eternal, ongoing process of cosmic order and harmony. It describes energy: the vital force which keeps the whole universal complex on the move. From the microcosm of the atom to the magnitude of the great, whirling bodies of matter in our heavens and beyond, there exists the ceaseless life-force of the $u r$ energy. $U r$ also describes time: time without beginning, time without end- time that continues its ongoing, rhythmic flow for no reason that we can comprehend, except to continue. Ur describes space: limitless extensions of space, existing without boundaries, far beyond the familiar stars, planets, sun, and moon of our galaxy into regions inconceivable. We humans, by the very nature of the evolutionary process, are linked to the $u r$ energy, the $u r$ time-flow, the $u r$ space. We are, 
indeed, a certain species of living matter conjured up by the combined $u r$ forces.

The $u r$ - incomprehensible as it is - is therefore the primordial portion in each one of us. Without the $u r$, there would be not life at all. (p. 91)

In contrast to the timeless, limitless $u r$ level (or track) of experience there is also a second level of people's experience of reality on this earth. This second level is the very human, time-limited, space-limited, energy-limited, experience, and the intense challenges of daily living it entails. Schoop wrote, "and here is where I think dance enters the picture of the double-track experience I have drawn. I think dance expresses both spheres of awareness" (2000, p. 93).

Looking at Schoop's cosmological beliefs is important in that it begins to give us a possible understanding of how Schoop was able to move so fully into her emotions and help others do so, to experience what might be considered the challenges of living on this earth, but to hold this inside a container of connecting with a deeper, universal, spiritual knowing.

It is possible that her ability to integrate her experiences combined with her connection to a deeper source played a role in her sense of joy and aliveness. In Schoop's quest to become a more whole person, "to encompass the complete range of every feeling, action, and thought - from the least to the most, from the smallest to the largest", (2000, p. 94) she helped people do the same.

In her own book, Won't You Join the Dance? (Schoop \& Mitchell, 1974), Schoop also wrote about her first experiences with dance and how healing those were for her, and how she learned to communicate through movement, and work through emotional challenges with dance. It is also interesting in this book to read her stories of how she 
began as a dance therapist, and her trying different courses of treatment, and her success and failures.

Schoop's Theories

Wallock's interview (1983) with Schoop gives us an example of some of Schoop's other theories on life. Schoop said:

I think most people are not really deeply involved in life. They look at life. They live, they drink their coffee in the morning, they earn money, they buy a dress; but, I think there are not many people who really feel they are living, that they have one chance to live, to see, to smell, to touch with all their senses. I think most people are bored and afraid. The more I teach, the more I realize I would like to involve the human being in life - in suffering as well as in beauty and harmony. I think we would be happier. I think we are very unhappy human beings...I think when you move you become involved and you learn to love yourself. When you love yourself you love life, you love others, you love! (p. 6) Schoop continues:

I think basically it's about being able to say yes to life. I believe that all people have a right to be here, and that being here has an important reason. I would really like to make people believe that. And I also believe that to dance is wonderful; with movement you change the chemistry of your body. I'm absolutely sure...If you dance you include the whole human being, not just the intellect. (p. 12) These views were reinforced in Claudia Wilke's 1993 documentary The Conquest of Emptiness: Encounter with Trudi Schoop. In this film, which includes an interview of Schoop, Schoop talked about how people do not walk fully committed, part of them may 
be going forward and part holding back, and how often they are only partially engaged in life. She leans into the camera and with full gusto says there are very few people who walk fully integrated, and then she leans back and smiles, waves her hand, and says, "and that's okay too."

In Come Dance with Me (1991) Wilke takes a longer look at Schoop facilitating groups of people with schizophrenia. This documentary offers incredible insight into how Schoop interacts with clients, and her powerful presence. During this footage we see how Schoop applies the theories she has previously written about.

\section{Personal Background}

Another source about Schoop's life is Therese Adams Young's master's thesis Trudi Schoop- From Dance Mime to Dance Therapy (1986). Young did a number of personal interviews with Schoop and researched her background. Young wrote about Schoop's political satire about the Third Reich while she lived in Switzerland during WWII. Young also included information about the progression of Schoop's career such as her early instructors and her first dance troupe.

Another source to read an overview of Schoop and her work is Sharon Chaiklin's write up of Schoop in National Biography (2002). She gives a brief look at where Schoop was raised and the progression of her career.

\section{Schoop's Methods}

The best sources for specific methods Schoop used with clients are in Dr. Chodorow's book Dance Movement Therapy and Depth Psychology (1991), Dr. Fran Levy's book Dance Movement Therapy: A Healing Art (1992), and Schoop and Peggy Mitchell's book Won't You Join the Dance (1974). 
In Dr. Chodorow's book she gives some extremely interesting methods from Schoop. She wrote about how Schoop was fascinated by every aspect of human expression. Schoop would get her students and patients, where appropriate, to try on every kind of movement, including the ways friends and family walked. She would also have them exaggerate movements, bring awareness to parts they liked about their bodies and dislike, and move how they thought their parents would like and dislike. Schoop had people foster congruence between intention and action. If they were indecisive every part of their body should participate in expressing that. They would also work on committing fully to movement. Schoop placed a very high value on clarity of expression. A further look at some of the methods and tools Schoop used is in Appendix B where Dr. Chodorow has very graciously agreed to let me include her notes of studying with Schoop $(2001,2006)$. I find they expand on the ones Dr. Chodorow included in her book, give more detail then I have found in other sources, and are invaluable.

In Levy's book she wrote about how Schoop thought that due to societal views parts of a person needed to go undercover. She quoted Schoop, "When I am intensely present in all my multifaceted totality, I feel that I am in balance. Thus, my approach to my work becomes an "attitude" rather than a "treatment""' (1992, p. 62). She also further described how Schoop would include improvisation, but she "stayed in this mode only long enough to bring out new personalized material. As this material surfaced, Schoop helped patients to organize their new experiences through movement 'performances,' that is, the planned reproduction and repetition of movement themes" (p. 64).

Of course Schoop's own book (Schoop \& Mitchell, 1974) gives a thorough look at her theoretical frameworks and some of the methods she used with patients. She wrote 
about the importance of humor, working with fantasy, working with rhythmic activity, and the importance of flexibility. She again covered the importance of working with conflicting emotions and helping clients exaggerate them to bring awareness to them.

Over all, these sources give a good view of Schoop's beliefs and how she taught. From these sources we see the beliefs and methods Schoop used to help herself and others become healthier. Some of the sources also describe the joy, love and humor she brought into her personal and professional relationships. However, what was missing from the literature was a deeper look at how she lived as a person outside her work, a deeper look at how she affected others and dance/movement therapy in the beginning of a young field, and a deeper look at what qualities people found so personable about her and attracted people to her. It is these things I sought to address with my thesis project.

As I mentioned, there was not an abundance of literature about Schoop. Again, that's one of the reasons I sought more information about her from interviews. There was also not a lot written about her after she passed away in 1999, and I wanted to know as much as possible about her, and not just what was in print. 


\section{Methods}

For my thesis project I arranged a panel of people to talk about their work with, or studies of Schoop, in a workshop at the 2009 American Dance Therapy Association (ADTA) Conference, in Portland, Oregon. The panel was comprised of five people: Dr. Cynthia Berrol, Sharon Chaiklin, Dr. Tina Stromsted, Susan Imus, and Therese Adams Young (Dr. Chodorow was initially scheduled to sit on the panel but was unable to make the conference for personal reasons) (See Appendix D, biographies). I conducted individual personal interviews over the phone with all of the panel members except Dr. Stomsted before the workshop to get a basis of information. By doing these interviews I received more information on Schoop, and I was able to discuss with panel members what we thought would be most important to share at the conference.

I began the workshop with introductions and an explanation of my research questions: "What were the qualities about Trudi Schoop that so many people appreciated about her (what was that light)?" "What did she do to cultivate those qualities?" and "How did she pass that on to others?" The panel members then talked for 5 minutes each about their experiences of Schoop. Then we showed the documentary The Conquest of Emptiness (Wilke, 1994), followed by audience questions, comments, and stories about people's experiences with Schoop. Audience members were also given questionnaires with the above research questions, to hand in after the workshop. Both the panel introductions and the discussion afterward were videotaped. The intention in recording the workshop was so that other people and future generations could share in the personal stories people had of their experiences with Schoop. I wanted to capture the emotion and aliveness of these stories on a DVD. 
This qualitative methodology served me well personally and clinically. My background prior to dance/movement therapy training was more in logic and business. My growing edge was and continues to be letting go of some formality, and opening up to more humanity (not that they are mutually exclusive). Thus, as I studied Schoop and her characteristics of warmth and strong interpersonal connection, it seemed only fitting to use a style of research that dealt with interpersonal connection. This worked hand in hand with my humanistic theoretical framework, which involves the experiences of people, down plays pathology and focuses on the healthy aspects of individuals. The data collected and presented here is comprised of the recording of the workshop, and a summary of individual interviews, the panel and subsequent discussion from the workshop, and the results from the questionnaires. I used snowball sampling (see glossary of terms), beginning with Dr. Chodorow, who agreed to be interviewed about her work with Schoop. Additionally, since Dr. Chodorow knew Schoop well, I asked her who else could be on the panel I was planning, and she identified the other members.

A chronological progression of this project follows:

\section{October 2007}

I presented a class project on Trudi Schoop. I saw a picture of her leading a group dancing and had a palpable feeling of joy and I wanted to know more. I did a phone interview with Dr. Chodorow, and I was deeply touched by how Schoop impacted her, and I also learned a lot more about Schoop. From Chodorow I learned more details and understood more fully how dangerous it was for Schoop to be in Switzerland in World War II in a cabaret that performed political satire about Hitler. Dr. Chodorow also later pointed out that Schoop was born in 1903 and was a young girl when the first world war 
broke out in 1914 and came to an end in 1918, and that Switzerland, a neutral country, was surrounded by nations at war. I would assume that would have to be at the very least extremely frightening.

After what I learned I saw Schoop in a more human light and more deeply understood the very difficult things she had lived through. With this understanding my respect for her grew tremendously, and I saw that she was not simply a fortunate person. Like many people, she had a challenging life, but she learned an alchemy that turned her challenges into gold, and through this learning she was able to have a profound impact on numerous others and to pass on her gifts. I became very curious about how she did this, and wanted to know more, and I started thinking of how to learn about how she did that. When Dr. Chodorow ended the interview by saying of Schoop, "I couldn't be who I am without her" I knew I had more to learn.

I then met with Dr. Lenore Hervey, who is in charge of research at Columbia College Chicago, and found out the path for completing a master's thesis. I checked the abstracts to make sure no one had done a thesis on Schoop like I was interested in doing. Then I started reading the literature about Schoop.

Spring of 2008

I met with Jessica Young, an instructor at Columbia, and ran my idea about getting together a group of people who studied with Schoop to discuss their experiences with her. She helped me refine the questions I had and listed some possible grants that could help me get funding for expenses for the conference.

Fall of 2008 
I met with Laura Downey, an instructor at Columbia, and told her about my idea to interview people who studied with Schoop, and to get them together for a conversation, and to record this for future generations. Downey suggested I do it at the ADTA conference.

Later I had a few conversations with the individuals associated with Columbia College Chicago's Weisman Grant and got a great deal of information about how to write a proposal for this grant that helps Columbia students complete large projects, including videos. I read a book they recommend on directing a documentary, wrote a grant outlining the "treatment, script, and synopsis" for my videotape, and offered my proposed budget. I did not get the grant but writing the grant proposal helped clarify my ideas and I used this as a basis for future grants and to understand how much funding I needed for the project.

I then found out Susan Imus, the Department Chair for Columbia College's dance/movement therapy and counseling program, studied with Schoop. Imus agreed to do an interview with me. I made calls and found a documentary student at Columbia to videotape the interview. He taped the interview and that gave me a clip of an interview, which I needed for my Weisman grant proposal. I found out Imus became a dance/movement therapist because of Schoop. I found this fascinating as Columbia's dance/movement therapy program had a profound impact on me, and Imus has had a very large impact on Columbia's program, and Imus became a dance/movement therapist because of Schoop. One of the reasons I wanted to study Schoop was because she had such a large impact on people, and I found out that it could easily be argued that through Imus and Columbia, Schoop had an impact on me. 
I then continued to look for ways to video the panel at the ADTA conference. I talked and emailed with people at film schools in Portland looking for a student to tape the panel, but I did not receive enough funding to follow through with this. Then in Research Methods class I read about the idea of many perspectives and people looking at a topic to distill information, and this reinforced my idea of the group conversation. January 2009

I approached Dr. Chodorow with the idea of sitting on a panel during the 2009 ADTA conference. She was very interested. After a number of conversations Dr. Chodorow and I worked out a format for the Schoop panel, which became a Schoop workshop.

I then applied for a grant from the Marian Chace Foundation for the project, and was declined. When I counter-offered and asked if they would simply pay for a graduate student to video the panel, they declined again.

Winter of 2009

Dr. Chodorow gave me a list of people to contact for the panel. It took me some research to find Therese Adams Young, who interviewed Schoop for her thesis. Dr. Chodorow, Dr. Cynthia Berrol, Sharon Chaiklin, Susan Imus, and Therese Adams Young all agreed to sit on the panel.

The panel members and I had numerous email exchanges back and forth refining the workshop. At first, for the proposed workshop I wanted to spend more time hearing from the panel members, but they agreed there needed to be time for everyone in the room to participate, and that none of the voices were more important than the others. I also thought it would be very interesting to have a movement experiential in the spirit of 
Schoop, but a few of the members were emphatic that they could not imitate Schoop's work, that they could not separate what their own styles had become, from those of the people they had studied with. In my wanting to know about the light coming from Schoop, in an email Dr. Chodorow wrote that it was loving. Working with the panel members setting up the workshop was invaluable for me as they often referred to what they thought Schoop would want or what would honor the spirit of her work. I learned a lot about Schoop and dance/movement therapy.

Spring of 2009

I applied for an Illinois Chapter ADTA grant and received \$308. I then applied for a Rosenblum Award from Columbia College Chicago, which helps students get to conferences. At the time of my first submission they had decided to discontinue the award, but the person who oversees the award liked my proposal and asked those in charge of administering funds if they would reconsider and re-open the award, and they did. I resubmitted my proposal in September of 2009, and received \$500. I was extremely excited when I found out I would have enough money to get to the conference. But after finding I would not have enough money to hire a graduate videographer I emailed around looking for someone to tape the panel, and people volunteered to tape it with personal cameras.

February of 2009

I submitted the proposal for the panel workshop to the ADTA, and it was accepted. I then had a conversation regarding my thesis with Dr. Hervey. I told her about my visceral feeling of joy when I saw some pictures of Schoop and wondered if other people had the same reaction. I also discussed how there seems to be a light coming from Schoop when I 
saw pictures and tapes of her, and I want to know what that involved, and wanted to know more about the qualities of Schoop.

Dr. Hervey suggested the possibility that during the viewing of the Schoop documentary during the ADTA conference, people could name when they notice something specific about Schoop, or a sense of joy, or the light, and say "there" or something to that effect, to start to distill out the qualities. I later modified that idea to having people name things about Schoop when they saw that light and to put it on large flip charts and paste them around the room. Dr. Chodorow suggested this didn't seem in keeping with Schoop's own groups, and thought it might detract from the workshop. I was clear however, I did not want to sit alone and dig through data and synthesis it solely myself. That was my default pattern and too easy for me. I also knew that I had a lot to learn about Schoop and dance/movement therapy, and I was concerned that with my blind areas I would leave out too much or miss significant data.

I later modified the flip chart idea to passing out handouts and having audience members write down during the workshop their ideas on my research questions. This obviously grew the number of perspectives or lens from five on the panel, to as many people agreed to fill out questionnaires. That felt right to me.

Summer of 2009

I did individual phone interviews with the panel members.

October 2009

I heard from Dr. Chodorow that she could not make the workshop. She said Dr. Tina Stromsted would bring the Schoop documentary to the conference. Interestingly enough, when I asked someone at the conference if they knew who Dr. Stromsted was 
she said, "yes, she's in the other room, she has blond hair, and she has this beautiful light coming out of her eyes." I remembered I started the journey wanting to know what that light was coming from Schoop, and I knew I was on the right track. I met Dr. Stromsted at the ADTA conference and asked her to sit on the panel and she agreed.

October $9^{\text {th }}, 2009$

We had the workshop. That morning Therese Adams Young informed me it was also Schoop's birthday. We watched the documentary A Conquest of Emptiness, talked about Schoop, and at Imus's suggestion we sang Happy Birthday to Schoop. I felt a lot of joy and connection as we sang and I celebrated Schoop with others, in an expressive, joyful, and connected way which reminded me of the stories I had heard about Schoop. Her presence and legacy was very much in the room.

To synthesize the information I gathered from the interviews with people who studied with Schoop or studied her work, I copied all of my notes and questionnaire answers to a word document, then read everything over again. I then pulled out common themes and quotes and created a list I still had a wealth of information so I took a break from the information and came back later. I then set up categories and distilled the information further onto a shorter list.

I originally started my thesis project wanting to distill information from Schoop's path and work it into some sort of repeatable patterns. My work at creating this list was derived from that wish. After repeated feedback from people who read the first drafts of my thesis I agreed to reorganize the list, and later I removed it. I then included the quotes I gathered from my project into a summary for my Results section. 
I have a tremendous respect for people who can distill work and spiritual paths into concise and repeatable formats and it was my sincere hope to distill Schoop's work into a template I could use as a reference. From the start of this project however, I grappled with the fact that Schoop's work was very much about individuation, and yet I was studying her path, work, and patterns. I quote:

According to my concept of the whole person, we all encompass the complete range of every feeling, action, and thought- from the least to the most, from the smallest to the largest. But as I said before, it's damned hard to become an individual. In the process of doing so, our society or environment demands that we become selective; one feeling, action, or thought must be suppressed so another becomes dominant. What a toll such discrimination takes on our personalities!... Each human, I think, is driven by a longing to fulfill himself.. (Schoop, 2000, 96)

So I was balancing being profoundly moved by the work Schoop did toward her own individuation, which seemed to have such great rewards for her and others, and trying to learn the patterns by which she accomplished this, with the obvious fact that to individuate, you need to find your own path. As I mentioned, I did not end up with a list, nor did I end up with a template. For my own personal path I include many things, and one of the ways I have included an aspect of Schoop's work is to see a dance/movement coach. As we continue to look at areas in which my movement is inhibited, or to move beyond my ingrained movement habits, it never ceases to amaze me how parts of me that have been in shadow or pushed aside come to the fore. I am challenged and rewarded as I explore what Schoop called "my multi-faceted totality." In the following Results section 
below, as mentioned, I have included a summary of the interviews and questionnaires, many of which support the positive results Schoop had with her own individuation and growth. 


\section{Results}

The purpose of my thesis project was to create a documentary style DVD of dance/movement therapy professionals talking about their work with, or study of, noted dance/movement therapy pioneer Trudi Schoop. My research question was: What were the qualities about Schoop that encouraged so many people to care about, respect, and be influenced by her, and what was she doing to cultivate those qualities and pass them on to others? The literature often talks about Schoop's sense of humor, spontaneity and authenticity. With my research I take a deeper look at how Schoop developed and used these and other traits.

The following results section includes quotes that are distilled from the written materials, the questionnaires from the workshop, and the individual interviews, to illuminate some of the qualities, actions, and tools of Schoop. As mentioned, the questionnaires asked the audience the following questions:

1. What were the qualities about Trudi Schoop that so many people appreciated about her (what was that light)?

2. What did she do to cultivate those qualities?

3. How did she pass that on to others?

The quotes from audience members are as the audience wrote them. The quotes from the individual interviews are paraphrased from my notes of our conversations and are not exact, and may include some of my own words as well as theirs, and are parceled out from much longer conversations. All interviewees have given me permission to use these quotes via email, and one of my purposes with these quotes is to bring to life some of wonderful sentiments, feelings, and thoughts people have about Schoop. The recording 
of the panel is another vehicle for this. I think it is important for people in the future who are interested in Schoop's work to have access to some of the results of her work, i.e. the warm feelings and memories people have of her.

One of the things that came up repeatedly and seems to be an important part of Schoop and her work appears to be her personality. People really seemed to enjoy her and being around her. When people talk about Schoop they often have a smile, and they light up. Regarding her sense of humor Chaiklin said, "Humor was important to Trudi, you could relax and laugh, she was someone you could be comfortable with." Therese Adams Young described Schoop like this: "Trudi was comfortable and fun to be around. She put people at ease. She was at ease with herself," and "We really connected in a way I didn't expect. I don't know if she had that effect on everyone." Young also said, "Trudi had a very open, welcoming appeal. She was a very comfortable person to be with, to talk with, very down to earth. It was like spending time with extended family."

Regarding Schoop's ability to connect with others, one audience member from the panel put it this way, "She seemed fully present to self and others." Another audience member wrote of Schoop that she was a "Physical, human, loving, transmission of spirit." An audience member answering the question of how Schoop passed on her gifts wrote that Schoop used "Love as a clinical skill." All of these statements help reinforce what Dr. Chodorow said, that people, students, etc., "fell in love with her."

It is also clear that Schoop had a strong presence and made an impact on people. When I asked Chailkin what came to mind when she thought of Schoop she said "She emanated all this energy." Another audience member from the Schoop panel described Schoop this way "She was a 'container for life.' She embraced and embodied the 
complexity of life. She embraced the range of human beings and our expressiveness. She was a totally committed 'mover/dancer.' Gutsy. Her 'presence' was so palpable." These statements give us a glimpse into what it was like to be around Schoop. She was very expressive and warm. In describing what Schoop did to cultivate the qualities people admired about her one audience member wrote, "Dance, Dance, Dance! Observe, observe, observe! Speaked her mind; expansive (rather than contracted in expressing her essence).”

When I asked Susan Imus what she thought might have led to people being so drawn to Schoop, Imus mentioned it might have been related to Schoop's posture gesture mergers, her full body movements, and Schoop being so fully committed to her movements. I found this to be true when I later watched a documentary about Schoop, I saw that, as usual for me, it was a pleasurable experience to watch her on screen. However, when Schoop imitated someone walking in a disconnected way, I no longer felt that pleasure. The thought of Schoop's commitment to her movement was also mentioned by an audience member at the Schoop workshop, when asked what drew people to Schoop she wrote "Commitment to feeling the dance. Commitment to bringing her entire self into the dance with others."

We also know that Schoop not only moved fully, but lived fully. As Young says of Schoop, "She seemed very peaceful and content. She lived every day the best she could. She made hard decisions and good decisions that affected people in positive ways. You have to be a centered individual to help people the way she did. She had such courage helping Jewish dancers get out of Germany through the use of her dance troupe." 
Or as an audience member from the workshop wrote, "She was real and honest and not afraid to say and do what was right.”

It's clear that Schoop's teaching had a large impact on a lot of people, to quote another audience member "Trudi Schoop seems to have mastered use of self in the best sense - she used (or came from her true Self) to serve the bigger picture - to serve life she stayed [in] connection to the opposites and was present in such a full authentic way it pulled people to her."

Although along with all the statements about Schoop's love it also appears that she could be very direct. Chailkin said, "She did demand you do things, a certain expectation to do something you thought you couldn't. But as in her book, she also had great patience." Or, even more directly, one audience member wrote this of how Schoop passed on her gifts, "Challenge and confrontation. Love."

I was also personally surprised at how often structure was mentioned in the interviews. Imus stating an often mentioned theme, said that "Trudi was very educational, very structured." Although within that context, it is also clear that Schoop came across as very down to earth. To quote Chaiklin again "Trudi saw her work with her clients as 'what can I learn from them' vs. 'what can I do to change them?'” This theme of attuning to and connecting to others was another common theme from people.

Schoop's curiosity also came up a lot. Again Chailkin says "We spent a whole class exploring a swing of an arm." This curiosity is further reinforced by Dr.

Chodorow's notes of sessions with Schoop (appendix B). I personally believe it is this curiosity that helped Schoop stay so vital and alive, and to have such a sense of wonder into her 90s. We also know Schoop's connection was not limited to people. As she 
described in her interview with Wallock "I danced flowers, I danced birds, clouds, danced the trees and like the corn in the fields" (p.8). This connection with nature and animals also came up repeatedly in the interviews.

Overall it appears from the written materials, interviews, and Schoop's own writing that dance played a huge role in her healing and as a driving force for who she became (Wallock). The qualities about Schoop that came up repeatedly were her sense of integrity, her humor, her compassion, her authenticity, and her love for animals, nature, and others. Other common themes are her curiosity and insight.

Finally, one of the most important things about Schoop was how she consciously used the skills she had cultivated as a mime/comic/dancer. A foundational theme throughout Schoop's work is not only that she cared about people and had a lot of wonderful qualities, but also that she knew how to attune to others and consciously communicate to others her feelings of warmth and compassion. To quote Schoop:

The projection of oneself, which is so important onstage, continues to be important to me in a hospital setting. I can project all my respect and all my love to the people I work with. I can show them my feelings, and they can show me theirs. More and more, the deep joy and excitement to be alive, which was partly lost in my darker days, came back to me fully, and I am aware that I project this joy of life to the ones I work with. (T. Schoop, personal communication, January 27, 1985) (Therese Adams Young, p63). 


\section{Conclusion}

In studying Schoop's work I wanted to embody her values of humanness, being in the moment, and sense of relationship. Reviewing her work in the context of the dance/movement therapy community during the ADTA conference was congruent with Schoop's values, from what I know of them. While there was subjectivity in that the interviews were people's memories and opinions, there was also a lot of consensus among the information I gathered. I also brought in many of my own limitations. I found myself considering not adding things that weren't as important to me. For example, I didn't include anything about "rhythm" at first although one interviewee thought that was important. Rhythm didn't have as much meaning for me and I almost overlooked it. Also, although almost all of what I heard about Schoop was positive, that in itself is a limitation.

However, many people also told me afterwards how helpful the workshop was for them, and several people told me how grateful they were that we could get together as a community to celebrate and remember Schoop's work. The interviews also uncovered information about Schoop that was not published and the appendix includes personal notes about classes with Schoop. The DVD also includes the emotional component of seeing how touched people were by Schoop's work, and that is invaluable. With that in mind I believe my project met its goals.

As far as things to do differently, if I had more time to do a larger project I would interview more people and as many of Schoop's family members as I could. I also wish Dr. Chodorow could have made the panel. I have this dream of seeing Schoop's story made into a full length main-stream movie (not a documentary). If someone were to carry 
on research I would like to see them do in-depth interviews and take Therese Adams Young's work and make a biography about Schoop. I think it would be fascinating.

It would be helpful to have more formal research into Schoop's background. One of the questions I had at the beginning of this project was that if Schoop's childhood was idyllic (Frieder-Wallock, 1983, p. 7), how did her self-described obsessivecompulsiveness, described as similar to schizophrenia, originate (p. 96 Schoop)? That is, if her illness was non-organic and she was able to heal herself through dance, what was it that she had to heal from? I heard ideas and rumors from different discussions but I didn't walk away with enough clarity on this topic. In Schoop's own writing and in Young's thesis, we are never given the details of why Schoop was afraid and turned to her obsessive-compulsive behavior. In fact, her growing up through World War I, to my knowledge, was never mentioned. In some respects, the information as to what frightened her may be immaterial. From the information I gathered Schoop presented herself as a well-adjusted, content person, and whatever it was she worked through no longer seemed to haunt her.

Anther interesting part of this project, to me, is that when I started my Master's Degree in Dance/Movement Therapy I had no background in dance. As mentioned previously, I was interested in Schoop because of the look of joy and connection (that light) she had with the group she was leading in the photo I saw of her, and the palpable vicarious feeling of joy I felt looking at the photo. This project helped me understand on a deeper level the healing power of dance in general and with Schoop's work. As in my interview with Dr. Chodorow where I ask numerous times, implicitly, "What was Trudi really doing to become so fully herself and to grow and deepen and connect with others?" 
I was expecting to hear about meditation or yoga or something along those lines. Dr. Chodorow said a number of times "She danced." Hearing Dr. Chodorow talk about how important dance was to Schoop's healing began to open my awareness to the power of dance.

It has been a gift to spend two years reading, watching documentaries, doing interviews, and talking about Schoop and her work. With each assignment, literature review, thesis proposal, planning the ADTA workshop, collaborating with the panel, applying for grants, doing the workshop, writing my thesis, etc., my understanding of Schoop and her work has grown. One of the most valuable things I learned from this project was seeing the depth that was in Schoop's teachings, and how I needed to keep going over them and over them and learning them at a deeper level, and how I could continue that for the rest of my life. I have a tremendous respect for Schoop's life and work and to me this study has also been a study of a life well lived, and I trust my understanding of her work will continue to deepen as well as my understanding of how to live life more fully and deeply, with commitment, passion, mindfulness, and love. I also now understand more fully that Schoop's dance/movement therapy is a path unto itself, and it yields incredible gifts.

Furthermore, a number of the perspectives I had when I first started this project have shifted. When I first read about Schoop's description of the ur experience I thought it too esoteric and translated it in my mind to simply her connection to the universe. However, even with my present limited understanding, my respect for the $u r$ experience has continued to deepen as this project unfolds. As I was finalizing this thesis and looking for a quote on the $u r$, I saw how closely her description of the $u r$ correlated to my studies 
of her, what seemed to be her connection to the "cosmic," "transcendental," "vital force," the "timeless," and "limitless." I included the long ur quote in the Literature Review to give more of a description to something that is not easily summarized but very important. What has also deepened my understanding of Schoop's work has been applying her principles as best I can in my own life. I keep seeing the cyclical nature of what she taught and lived, and how when I work with her beliefs and theories how that influences my behavior, and in turn how my changed behavior deepens my understanding of her beliefs and theories. When applied, the behavior and theory live and breathe together in a continuous living loop. For example, I was working with Schoop's idea of working with people as if I had a hundred years to work with them, that is not trying to fix people, and not being in a hurry, but giving both myself and my client the time and space we need. I was also working with Schoop's belief, "that all people have a right to be here, and that being here has an important reason" (Schoop in Wallock, 1983, p. 12). I was doing this during a session with a client and I found myself opening up, letting go of my need to have the client feel better, and I felt a deeper sense of compassion and spaciousness, and events unfolded in the session much easier. I saw how I had previously been forcing things and it wasn't helping. Later that day I had my own personal challenges, and in turn I felt for myself the same acceptance and spaciousness I had earlier felt for my client. This in turn made me feel more relaxed and open for my next client, and I really did feel like $I$ was supposed to be here, and that $I$ had time and could accept myself and grow in my own time. It felt really good. I realize that having compassion, patience, respect, and warmth for a client is not new, but studying and immersing myself in Schoop's work on a deeper level helped me integrate specific ideas more fully. 
Another important point for me in this project was when our Dance/Movement Therapy Program had a performance celebrating our graduation. As students we could do whatever we wanted in the performance. I was studying Schoop, who repeatedly writes about "the importance of the two tasks we can [have in] dance therapy: First, the bringing into awareness of any inhibiting or denied feeling. Second, the full expression of this feeling and, even more important, the arranging of those feelings into an artistic form" (Schoop, 2000, p. 98). I didn't want to do a performance but it was nagging at me, knowing that in never having done a performance like that I had not experienced such a large part of Schoop's healing methods (although I had done much smaller one or two minute pieces in front of my classmates and found them very healing).

So I signed up for a performance, during which I moved places inside of me that I did not want to show people, places of fear, anger, longing, hunger, and I ended the piece by stepping into a very deep fear of mine. During my dance/movement therapy program, it was very challenging for me at first to move in ways that were lighter, more indirect, free flowing, and slower, basically what are considered more feminine movements (this was even more challenging as I was the only man in the class). Throughout the program I had to work through messages I had from playing football and sports about how I could and could not move as a heterosexual man. At the start of the dance/movement therapy program I would sometimes literally shut down and not be able to do these softer movements, especially in front of people.

I decided that I would do these movements in the performance in front of the audience in the spirit of Schoop's ideas of the symbolic expression of every emotion, and of bringing inhibited or denied feelings into awareness and then into an artistic form. I 
also felt that in society as I had experienced it, what might be considered more feminine values (e.g. tenderness, softness, vulnerability) had been devalued and even denigrated, and I had remembered how intense the homophobia was growing up playing competitive sports. These were also reasons people I knew from growing up didn't dance; dancing was looked down upon. Even as an adult I got some jokes and comments when I told people I was in a dance/movement therapy program.

So I decided I would step into my fear and I asked one of my classmates who had studied ballet and moved beautifully with soft, flowing movements if she would step out onto the floor near the end of my performance and lead, and then join me in soft flowing movements. She agreed, and that was how we ended my piece. I was very nervous before my performance and couldn't believe I was going to do what I had planned. I did do it, and I was incredibly supported by everyone afterwards. It felt wonderful. During the piece I moved places I didn't want anyone to see and moved in ways I had locked away, and I had been fully accepted afterward. I felt so alive and connected when I was done. I also felt this growing sense of compassion, acceptance, and love for myself. If this many people could see my most hidden places and embrace me afterwards, how could I not embrace myself?

Moving in ways I had previously shut down in my performance and feeling more open, clear, and connected to myself and others also correlates with what I learned in the interviews where panelists kept talking about Schoop's integrity with the choices she made. She took extreme risks to perform the political satire about the Third Reich in her cabaret when she was in Switzerland during World War II. She also helped Jews get out of Germany by hiring them for her dance troupe. From the Schoop documentaries I saw 
how her movements are not the movements of someone who has lived a frozen, pseudosafe life, shutting down her truth and light. I have little doubt that all the work she did moving, expressing, exploring, learning how to commit fully to her movement - helped her commit fully to her life. This commitment helped her to make difficult choices, full of integrity, which led to more clarity, light, and more expressive and committed movement. And conversely, how internalizing problems, and shutting down as a child led to repetitive, obsessive, deadening movements, which continued the deadening cycle of obsessive thoughts (Schoop in Wallock, 1983, p8).

As I mentioned, Schoop's work is so filled with valuable information it is still sinking in even after studying it for two years. I am still understanding more fully her idea of mind/body/movement unity. Schoop wrote:

[In] Won't You Join the Dance? we stated a credo to the effect that mind and body are in reciprocal interaction: so that whatever the inner self experiences comes to full realization in the body, and whatever the body experiences influences the inner self. Today I feel quite differently about this premise. When I think: "This is it. All at once. An entire ur-real person. This whole conglomeration is a unit." We wouldn't look at an animal and ask ourselves which part of it thinks, and which part acts, and which part dreams. We accept the animal as a whole organism. I feel exactly the same why about us. (Schoop, 2000, p. 94) It has taken two years since I first read this to shift the translation in my mind from "it's like we're a unity," to "we are a unity" of mind and body. One of the main things I have taken from this project is now I also consider myself a unity of mind, body, and movement. After seeing how Schoop's actions of integrity, commitment to life, and 
commitment to moving fully are a unity, I began to watch how that occurred in my own life. I saw one example, when I was grappling with an ethical question. I wanted to copy a $\mathrm{CD}$ belonging to my workplace to use in another workplace for my dance/movement therapy groups. However, I knew from past experience that every time I saw the copied CD I would think about how I copied it and feel out of integrity for copying something that was valuable to me, when I believed the artist should be paid for what they created. My wanting to copy the CD and not pay for it was fear-based. I believe this fear-based thought was related to the fact that I had not had the opportunity to move or dance much for a while, and was feeling physically, emotionally, and mentally constricted. From this place of constriction I was having constricted, fearful thoughts. However, after a dance class one day and a body/mind healing class another day, I felt this deep sense of well being and pleasure, and simply enjoyed being in my body and moving about my day with very wonderfully alive senses. From this place of expansiveness, connectedness, and well-being the decision was clear: I could afford the CD and I would not want to cheat myself out of the full pleasure I would have when I played it by thinking about how I had not paid the artist for their wonderful work.

My movement choices or lack thereof are a part of me as a whole organism. I am not person $\mathrm{A}$, moving in $\mathrm{B}$ manner, having $\mathrm{C}$ thoughts, as though my mind and body and thoughts were separate. The collection of all of me is who I am. I have different thoughts and make different choices depending on how I move, and vise versa. This may be selfevident to some, but it has taken me time to remove this compartmentalization to see the totality of me. I believe this lack of compartmentalization is one of Schoop's greatest gifts. 
As I mentioned, I also found out from my last viewing of The Conquest of Emptiness that I do not have the same feeling of pleasure I usually get from watching Schoop when she is demonstrating how people who are split off and compartmentalized walk. That was extremely interesting and important for me to learn. I saw how pleasurable it was for me to watch someone (Schoop) who is so fully committed to their movement. When she moves forward, all of her moves forward. I watch now as I go down the street and see people advancing with one part of their body and retreating with another, or tentatively reaching for something in a store in a non-committal, disjointed way, or some other such split. I wonder how this is playing out in their lives, their choices, their ethics. I notice how I do this in my own body. I see how my ethics, choices, thoughts, movements, etc. are a part of this unity of me.

In keeping with Schoop's ideas of performance I also crafted and told my story of what it was like to be the only man in my dance/movement therapy program, and to not dance when I started the program. I did this at a National Public Radio "The Moth" gathering. The Moth is a National Public Radio program that broadcasts everyday people's stories. They were in town in Chicago hearing stories about the topic of school. There were well over two hundred people in the audience. Before I went on stage I invited in Schoop's patterns and thoughts about animation and projecting thoughts and emotions into the audience. My story was very well received. I love the idea of turning the challenges of life into artistic form.

After taking these intimate places inside me and sharing them in my school performance and my story on stage I felt very connected, and not as tied down to my own personal story and strife, but more connected with others, with life, and with the larger 
picture. More and more I am seeing the importance of Schoop's idea that, "once we have dealt with our problems we are no longer preoccupied with them. We then can be fully present for the people we work with" (Schoop, 2000, p. 100).

I am filled with gratitude for the lessons I have learned doing this project. This work has profoundly changed my life. I have kept the written the list of Schoop qualities and actions that I began my thesis with, which helps me as a reminder, so I can review periodically what I am doing well and where I may need to grow. For example, am I living with integrity, making clear choices even when difficult, or am I shutting down part of myself, my light? Am I dancing, expressing, expanding, engaging my senses, living and loving fully or am I contracting, shutting down, going internal, limiting my movement and expression? I now believe passing on that light that I wanted to recreate in the beginning of my project is possible, and that dance is a vital part of that.

I believe my thesis project adds to the profession of dance/movement therapy because I started the project not being a dancer and discovered the power of dance to illuminate, heal, and act as a catalyst for growth, and that is a story that speaks to the power of dance and such stories can be beneficial to the profession. To be honest, as I thought about what thesis project I would choose at the beginning of the masters program, my hope was that it would not have to be dance related. So it was all the more surprising for me when I found out over and over the core of Schoop's healing was dance.

I also feel that the DVD of the panel talking about their work with Schoop is important for future students of dance/movement therapy. For students who learn by seeing things from a number of angles, they can learn about some aspects of the 
beginning of dance/movement therapy, and more about Schoop's life and work. I believe the video of the workshop gives others another lens and a more touching and human look at how Schoop affected other people.

Throughout this project Dr. Chodorow told me the information I was looking for was all in the materials, the interviews, the documentaries, Schoop's book, etc. To a large extent, I believe this is true. As I reviewed articles after the conference, and after watching the documentary during the conference, I see that the information and Schoop's path are all there. However, I have been blessed to hear the stories from many voices, to see the picture from many angles and lenses, and to have a reason to review the materials over and over, and I understand Schoop's work more deeply now. And I am grateful we have the conference tape and the emotional and heartfelt reactions of people who worked with Schoop for others to see. It feels more complete to me now. And I am filled with such love and gratitude as I write this. Thank you Trudi Schoop, for your life and your teachings, and may your teachings and the people you touched continue to leave a wake of goodness. 


\section{References}

Chodorow, J. (1991). Dance therapy and depth psychology: The moving imagination. London \& New York: Rutledge.

Chodorow, J. (2006, October). Encountering Trudi Schoop. Proceedings of the American Dance Therapy Association Conference, Long Beach, California. (p. 2)

Chodorow, J. 2001/2006. "Notes from studies and internship with Trudi Schoop in 1950s and 1960s," compiled in 2001 for teaching; updated in 2006 for lectures and teaching (via handouts and packets of reading material), pp. 1-3.

Chaiklin, S. (2002, May). Trudi Schoop. National Bibliography.

Levy, F. (1992). Dance movement therapy: A healing art. Reston, VA: National Dance Association.

Young, T.A. (1986). Trudi Schoop - from dance mime to dance therapy. (Unpublished master's thesis) Texas Woman's University, location.

Schoop, T., \& Mitchell, P. (1974). Won't you join the dance? A dancer's essay into the treatment of psychosis. Oxford, England: National Press.

Schoop, T. (2000). Motion and emotion. American Journal of Dance Therapy, 22(2), 91101.

Wallock, S. F. (1983). An interview with Trudi Schoop. American Journal of Dance Therapy, 6(1), 5-16.

Wilke, C. (Producer and Director). (1993). The conquest of emptiness: Encounter with Trudi Schoop [Motion Picture]. Berlin: Wilke-Film Production

Wilke, C. (Producer and Director). (1991). Come dance with me. [Motion Picture]. Berlin: Wilke-Film Production. 
Appendix A

Glossary of Terms

Humanism: any system or way of thought or action concerned with the interests and ideals of people. (Webster's New Twentieth Century Dictionary, Second Edition, Unabridged, 1979. Simon \& Schuster New York, New York)

Humanistic: of, belonging to, or characteristic of humanism. (Webster's New Twentieth Century Dictionary, Second Edition, Unabridged, 1979. Simon \& Schuster New York, New York)

Qualitative methodology: Qualitative research methodology is interpretive (vs. quantitative research methodology which is objective). (Dance Movement Therapists in Action, 2004, p. 210. Charles C. Thomas, Springfield, Illinios)

Rhythmic activity: Rhythm that occurs individually or in a group. This can have therapeutic benefits in dance/movement therapy. (Foundations of Dance/Movement Therapy: The Life and Work of Marian Chace, 1993, p. 81. Marian Chace Memorial Fund, Columbia, Maryland)

Snowball sampling: In research the act of selecting one candidate to collect information from, and this person in turn selects others who would be useful to collect information from. (Trochim, William M.K. "Nonprobablity Sampling." Research Methods Knowledge Base. 22 Feb. 2010. http://www.socialresearchmethods.net/kb/sampnon.php.. .

$U r$ : “... a German word. The closest translation I can find in English are such terms as "cosmic," "universal," and "transcendent." The ur principle denotes the eternal, ongoing process of cosmic order and harmony. It describes energy: the vital force which keeps the whole universal complex on the move." (Schoop, 2000, p. 91) 


\section{Appendix B}

Below are Dr. Chodorow's notes from studying with Schoop. While the panel was emailing each other deciding what form the Schoop workshop should take at the ADTA conference, Dr. Chodorow graciously emailed the group a copy of the notes she took from her sessions with Schoop. I did not incorporate them into my results or use them as a data source. They are for interested people and/or for people to use for their dance/movement therapy groups. I have retained her original formatting. They are as follows:

\section{TRUDI SCHOOP}

Chodorow, Joan. 2001/2006. "Notes from studies and internship with Trudi Schoop in 1950s and 1960s," compiled in 2001 for teaching; updated in 2006 for lectures and teaching (via handouts and packets of reading material), pp. 1-3.

(C) Joan Chodorow 2001

(C) Joan Chodorow 2006

Trudi's sessions offered a seemingly endless stream of motivating images.

The images are simple, yet tend to take the mover directly to and through deep material.

Energetic warmup: (usually begin with group standing in circle)

body parts up-down: head, shoulders, elbows, hands, feet

demi plies

tendus

leg swings

leg swings to whole body swings and jumps

follow the leader, "do what you like to do"

Progressions across room, (or take turns going round circle, or find a space in room):

Play with imaginary balls, big, tiny, light, heavy

Carry imaginary suitcase

Smoke a cigarette

Walk into a fancy restaurant

Walk down a crowded city sidewalk

Try crossing a city street at rush hour

Try getting on a subway at rush hour

Discover each sense, as if for the first time:

Sight

Sound

Smell

Taste 
Touch

In addition to the classic 5 senses that orient us to the outer world (exteroceptive), somatosensory experiences orient us to the inner world (interoceptive), including:

Muscular

Temperature

Pain

Visceral

Vestibular

Billions of receptors located all over the body provide an ongoing stream of sensory experience from the world and the self.

Trudi encouraged her patients and students to face life fully, to experience and express our sufferings and joys. By trying to avoid what we are feeling, we may avoid the full experience of life. Can we find the courage to be fully present, through all of our senses and emotions?

"You are the first humans on earth. How would you move if it is a:

Beautiful sunny day

Gathering clouds and rain

Thunder and lightening

\section{Progressions (or statues, or dances)}

"How do you move when you're feeling..."?

Afraid

Angry

Sad

Disgusted

Ashamed

Surprise (joyful)

Surprise party?

Delicious fragrance?)

Surprise (crisis situation, sometimes with resolution):

Fear of unknown?

Confronting intruder?

Finding injured animal and caring for it?

Coming upon bad smell?

Sudden shock of an embarrassing moment?

Explore and play with other affect sequences

Explore and play with affect blends.

Explore and play with body splits (smiling face with angry fists, etc)

Trudy taught her students to "try on" the gait and posture of each other as well as the gait and posture of different patients we worked with:

Chin out, elbows back, fists tight 
Shoulders up, bulging eyes, tense horizontal mouth

Rocking, heavy, weepy eyes, mouth down

Hand-wringing, nervous

Legs turned inward, shrinking, hiding

Frozen, eyebrows raised, open mouth

Own gait and posture:

What body part do I like?

What body part do I dislike?

What leads?

What stays back?

What hides?

What stands out?

Gait and posture of family and friends

Mother's gait and posture

Father's gait and posture

Gait and posture of other relatives Grandparents, siblings, aunt, uncle

Gait and posture of teacher?

Gait and posture of best friend?

Gait and posture of spouse, or child, or other family members?

Pleasing parents

Displeasing parents

Pleasing or displeasing myself

Small circles:

Go round and show each person how you would move if you don't like them (pretend,, as if).

Do it your own way.

Go round and show each person that you like them very much,

Do it your own way.

\section{Small groups:}

Choreograph a biblical story or theme

Choreograph someone's dream or vision or fantasy or delusion

Choreograph a myth or fairy tale or other story

Choreograph a theme of the "Many in the One": Circus? Zoo? Skating rink? 
Trace and dance the history of life on earth:

amoeba

fish

tadpoles

lizards

birds

small scampering mammals

large wild animals

dogs, cats, monkeys

humans

End with:

skipping

prancing

stamping

kicking

Pretend to dress up in the most elegant clothing (Vienna in 1700-1800s?) and dance with each other with many bows and curtsies to beautiful, music 


\section{Appendix C}

Below are the answers from the questionnaires I handed out at the Panel Discussion about Schoop. I have abbreviated my questions. "Q" = the question "What were the qualities about Trudi Schoop that so many people appreciated about her (what was that light)", $\mathrm{C}=$ the question "What did she do to cultivate those qualities", $\mathrm{P}=$ the question "How did she pass that on to others." A question mark "?" means that I could not fully understand the writing. There were approximately fifty people in attendance and I got back thirteen questionnaires.

1.

Q Something about gifts. How do we recognize them in others? Something about pain.

C By being authentic

2.

Q Integrity, humor, dancing, hug doctor, her god Leo Buscalla

$\mathrm{C}$ Looking for affect frozen in time. Crossing room as many different ways as possible.

P Fully embodying life

3.

Q Integrity, humor, humanity, bravery

C Lived life fully

$\mathrm{P}$ Through ? and example

4.

Q The love she felt for life and others

C She seemed fully present to self and others

$\mathrm{P}$ She was real and honest and not afraid to say and do what was right.

5.

Q She was a "container for life". She embraced and embodied the complexity of life. She embraced the range of human beings and our expressiveness. She was a totally committed "mover/dancer". Gutsy. Her "presence" was so palpable.

C Dance, Dance, Dance! Observe, observe, observe! Speaked her mind; expansive (rather than contracted in expressing her essence).

P Workshops and courses. But basically not "mincing her words", but telling others "how she sees it"!

6.

Q Kindness, openness, lack of fear, sense of humor, humility, ability to admit faults.

C Personal bravery to explore inner world and that of others. Looking.

$\mathrm{P}$ Relational ? Acceptance of a range of qualities/emotions.

7.

Q Acceptance of others. Connection of ideas? Humor. Energy, rhythm, melody, space, integrity. 
C Engage in story telling through dance. Searched to locate the feelings? ?

$\mathrm{P}$ She provided permission to work in both a confrontative and empathic manner without ? in illness?

8.

Q Sense of humor

C Eye contact. Self revelation of our fears?

$\mathrm{P}$ With dance, dance, dance.

9.

Q Warmth, integrity, political savvy, observation of people, humor, philosophical inquiry, she created relationships (by ? ? in their body). Life force. Playfulness. Love as a clinical skill.

C Studied people; related well to people. Valued place in her life of movement, space, rhythm, music. Turned her problems/fears/compulsions into art (dance). Mime, rituals, ceremonies. What are its colors, rhythms, etc. Stood up for what she believed.

P Her books, workshops, ripples of goodness. She asked others (demanded?) [question mark hers] to move on, expand, confrontative. Being real in relationships. Bring self to relationships.

10.

Q Commitment to feeling the dance. Commitment to bringing her entire self into the dance with others.

C She observed life. To Look. To take on another's bodily experience- to stand in another's shoes. To Love.

P Physical, human, loving, transmission of spirit.

11.

Q Humor, courage, integrity, humbleness, humanity, structured approach. Attention to detail, "intersubjectivity", engaging, inviting, passion, spiritual, precision, patience, persistence and will "I want you to...", connectedness, connection, wholeness/unity, joy, ugliness, imagination, play.

C dance, pantomime, embodying fears, listening to everyone. She "studied life", survival, turning fears/obsessions into art/form - creativity, experimentation, ritual, for expression, reading philosophy.

$\mathrm{P}$ Workshops, conferences, classes, performances, challenge and confrontation. Love.

12.

Q Trudi Schoop seems to have mastered use of self in the best sense - she used (or came from her true Self) to serve the bigger picture - to serve life - she stayed in connection to the opposites and was present in such a full authentic way it pulled people to her. 
Appendix D

Biographies of panel members and Dr. Chodorow:

Cynthia F. Berrol, Ph.D., ADTR, Professor Emerita, California State University, Hayward (CSUH) developed and coordinated the former Special Graduate major in Dance/Movement Therapy at CSUH; and has lectured and consulted—nationally and internationally. She has authored numerous dance/movement therapy related articles and is co editor of and contributor to research text Dance/Movement Therapists in Action and is on the editorial boards of three professional journals. She served as treasurer of the American Dance Therapy Association for four years and is an active member of the Research Committee of the American Dance Therapy Association. From 1993-95 she was Project Associate of the ADTA Demonstration Project studying the effects of DMT on older individuals with brain injuries and stroke, funded by the Administration on Aging of the U.S. Department of Health and Human Services.

Sharon Chaiklin, ADTR, a founding member and past president of the American Dance Therapy Association, worked for over 34 years in psychiatric hospitals and private practice. Her teaching includes the Graduate Dance/Movement Therapy Program at Goucher College in Baltimore, Maryland, and invitations to teach dance therapy in Israel, Japan, Korea, Spain, Australia and Argentina. Co-editor of the books Foundations of Dance/Movement Therapy: The Life and Work of Marian Chace and The Art and Science of Dance/Movement Therapy published in English and Spanish. Currently she serves as President of the Marian Chace Foundation. 
Joan Chodorow, Ph.D., ADTR is a dance therapist, Jungian analyst and one of the former presidents of ADTA. Dance therapy studies with Trudi Schoop led to continuing engagement with emotions and their forms of expression and transformation. Her books and articles are translated and published in many languages.

Susan D. Imus chairs the Department of Dance/Movement Therapy \& Counseling at Columbia College Chicago. Susan co-developed the College's Graduate Laban Certificate program in Movement Analysis and created the Making Connections Suicide Prevention Program at the College and in the greater Chicago community.

Tina Stromsted, Ph.D., MFT, ADTR, Jungian Analyst, licensed psychotherapist and Registered Dance Therapist, offers Jungian Analysis and body-oriented psychotherapy and consultation. Her international workshops integrate Depth Psychology, Authentic Movement, Somatics, elements of Marion Woodman's BodySoul Rhythms ${ }^{\circledR}$ approach, embodied dreamwork, and creative arts therapy.

Therese Young obtained a BA degree in Dance from the College of St. Teresa in Winona Minnesota in 1980 and continued her studies in Dance at Texas Woman's University where she graduated with a MA in Dance in 1986. She is currently the Director of the Dance Program at Central Washington University where she is responsible for curriculum and program development along with teaching dance history, pedagogy, choreography and dance technique classes. She also directs and develops original choreography for the University's performance dance company "Orchesis." 